\title{
Octenylsuccinic Aciduria in Children Fed Protein- Hydrolysate Formulas Containing Modified Cornstarch
}

\author{
R. I. KELLEY \\ The Kennedy Institute and the Department of Pediatrics, The Johns Hopkins University School of Medicine, \\ Baltimore, Maryland 21205
}

\begin{abstract}
The excretion of 2-(2'-octenyl)succinic acid (OSA) and several metabolites of OSA was studied by gas chromatography/mass spectrometry in 17 infants and children fed one of three proprietary elemental or proteinhydrolysate formulas that use OSA-modified cornstarch as an emulsifying agent. Variable but often large amounts (up to $2500 \mathrm{mg} / \mathrm{g}$ creatinine) of the fatty acid-like OSA and its metabolites were found in the urine of these children, and levels of OSA in their blood ranged from 9.5 to $57.9 \mu \mathrm{mol} / \mathrm{L}$. Apparently secondary abnormalities, such as increased urinary levels of glutaric acid and 2-ketoglutaric acid, were also found in more than half of the urine specimens. The molecular weight and mass fragmentation patterns of the nine compounds associated with the excretion of OSA are consistent with the proposal that OSA is metabolized in human infants and children by a combination of $\omega-\omega-1-$, and $\beta$-oxidation steps, similar to the metabolism of another branched-chain fatty acid, valproic acid. The urinary organic acid pattern of children fed elemental formulas containing OSA-modified starch often was dominated by OSA and its metabolites, and in several children the OSA-related changes were mistaken for a primary metabolic disease. Physicians and laboratories evaluating children for suspected metabolic diseases should be aware of the possibility of abnormal organic acid studies associated with OSA-containing formulas. (Pediatr Res 30: 564-569, 1991)
\end{abstract}

Abbreviations

OSA, 2-(2'-octenyl)succinic acid

OSA-TCA, 1,2,9-non-4-enetricarboxylic acid

TMS, trimethylsilyl

Since 1987, clinical laboratories that perform urinary organic acid gas chromatography for diagnosis of inborn errors of metabolism have been finding a complex organic aciduria in children fed one of several different elemental or protein-hydrolysate infant formulas. The unusual compounds, often present in large amounts, were easily recognized as an interrelated family of fatty acid-like compounds, but only recently has the parent compound been identified with certainty by high resolution mass spectrometry as OSA (1,2,-dec-4-ene-dicarboxylic acid), a component of one form of modified cornstarch (1).

When esterified to hydrophilic starches, OSA provides hydro-

Received January 11, 1991; accepted July 18, 1991.

Correspondence and reprint requests: Richard I. Kelley, M.D., Ph.D., The Kennedy Institute, 707 North Broadway, Baltimore, MD 21205.

Supported in part by Grants HD-07107 and HD-10981 from the National Institutes of Health and by a grant from the Muscular Dystrophy Association. phobic domains that enhance the emulsifying ability of starch. As a result, OSA-modified starch improves the mixing characteristics and stability of elemental or protein-hydrolysate formulas, in which protein is absent or the natural emulsifying properties of milk or vegetable proteins have been destroyed by partial proteolysis. OSA-modified starch has been used in prepared foods such as puddings and sauces for over 20 years, but only recently has it been introduced into specialized infant formulas. Because of the unusually large amounts of OSA and its by-products found in the urine of children fed formulas containing OSA-modified starch, and because many urine specimens containing OSA and its by-products show metabolite changes that cannot be directly explained by the metabolism of OSA, our laboratory has been collecting clinical and biochemical data on patients in whose urine we have found OSA. This report describes the organic aciduria associated with OSA-modified starch and the mass spectrometric characterization of nine apparent urinary metabolites of OSA.

\section{MATERIALS AND METHODS}

Patients were identified 1) through urine samples submitted to the Kennedy Institute mass spectrometry laboratory for testing for possible inborn errors of metabolism, or 2) as children who were hospitalized at the Kennedy Institute and were taking one of three formulas known to contain OSA-modified starch (Nutramigen and Pregestimil, Mead Johnson, Evansville, IL; and Vivonex T.E.N., Norwich Eaton, Norwich, NY). Random or 24h urine specimens were collected without preservative and stored at $-20^{\circ} \mathrm{C}$ before analysis. Heparin-anticoagulated plasma specimens (collected for diagnostic amino acid quantification) were also available for several patients and were stored frozen at $-20^{\circ} \mathrm{C}$ until analysis. Technical information about the content of OSAmodified starch and other components of the individual formulas was provided by the manufacturers.

Urinary organic acids were quantified as their TMS ether/ esters essentially as described by Tanaka et al. (2). Before acidification and ethyl acetate extraction, the urine was incubated at $\mathrm{pH} 11$ in the presence of $20 \mathrm{mg} / \mathrm{mL}$ methoxylamine to convert ketoacids to their methoximes and to hydrolyze organic acid esters (principally carnitine and glucuronide esters). To prepare methyl-TMS derivatives, the organic acid extracts were methylated with $10 \%$ (vol/vol) acetyl chloride in methanol at $70^{\circ} \mathrm{C}$ for $1 \mathrm{~h}$ before silylation. For gas chromatographic analysis, $1-\mu \mathrm{L}$ portions of the organic acid derivative mix, equivalent to $1 \mu \mathrm{g}$ of urinary creatinine, were injected into dual HP-5890A gas chromatograph spitless injectors leading to matched $0.2 \mathrm{~mm} \times 25 \mathrm{~m}$ methylsilicone $(0.25-\mu \mathrm{m}$ liquid phase) capillary columns (Ultra 1; Hewlett-Packard Co., Palo Alto, CA). The gas chromatographic oven was programmed from 60 to $290^{\circ} \mathrm{C}$ at $4^{\circ} / \mathrm{min}$ with an initial dwell time of $4 \mathrm{~min}$. Quantification of organic acids was performed by flame ionization relative to the internal stand- 
ard, undecanedioic acid $(250 \mathrm{mg} / \mathrm{g}$ creatinine). Because metabolites of OSA are not commercially available, more accurate quantification using specific response curves for each compound was not possible. Although organic acid concentrations are therefore reported without correction for extraction efficiency and detector response, the extraction efficiencies of most of the metabolites of OSA should be high. Studies with the parent compound, OSA, showed that extraction from urine under these conditions was essentially quantitative.

Organic acid peak identity and purity were determined by mass spectrometry using a Hewlett-Packard 5970A mass selective detector. The mass selective detector was operated in the electron impact mode with source temperature of $200^{\circ} \mathrm{C}$ and electron energy of $70 \mathrm{eV}$. Organic acids, other than OSA and its metabolites, were identified by comparison of the peak retention times and mass spectra with those of authentic standards. Racemic 2 ( 2 -octenyl)succinic anhydride was provided by the Humphrey Chemical Company, North Haven, CT, and converted to the free acid (OSA) by alkaline hydrolysis. By gas chromatography, $87 \%$ of the free acid was in the trans-configuration under these conditions of analysis.

Plasma FFA and organic acids were quantified as described by $\mathrm{Ng}$ et al. (3), using the same instrumentation and chromatographic system as described above for urinary organic acid analysis. Aliquots $(200 \mu \mathrm{L})$ of two prepared formulas, Nutramigen and Pregestimil, were analyzed for organic acid and fatty acid content by the same methods.

\section{RESULTS}

Data were collected on 17 children fed proprietary formulas containing OSA-modified starch, as summarized in Table 1. The children ranged in age from 3 mo to $6 \mathrm{y}$. Most were receiving the formulas for poorly defined recurrent vomiting. Only patients 5 and 15 had well-documented milk-protein intolerance. For all children except patient 3 , the formula provided at least $75 \%$ of calories. Compared with all children who are fed OSA-containing formulas, our patient sample contains a higher proportion of children with neurologic problems and a smaller proportion of patients with simple milk-protein intolerance or intestinal malabsorption, two of the principal indications for use of protein- hydrolysate formulas. However, at least four patients (nos. 12 and 14-16) were being fed elemental formulas for exclusively gastrointestinal problems and were taking no medications other than multivitamins.

Figure 1 shows a portion of a typical gas chromatogram of urinary organic acids from a patient fed Nutramigen, a proteinhydrolysate formula containing casein hydrolysate, corn oil, corn syrup solids, and OSA-modified cornstarch $(2.2 \mathrm{~g} / 100 \mathrm{kcal})$ as major components. The principal compounds in Figure 1 that are associated with the ingestion of OSA-modified cornstarch (Table 2) are: tricarballylate (peak A); OSA (peaks B and C); a tentatively identified tricarboxylic acid $\omega$-oxidation product of OSA, OSA-TCA (peaks J and K); an apparent structural homolog of OSA-TCA weighing two methylene units less (peaks D and E); and two pairs of compounds weighing $460 \mathrm{D}$, tentatively identified by TMS/methyl ester analysis as monohydroxylated forms of OSA (peaks F and G, H and I). In a few urine specimens, there were trace amounts of a pair of compounds with apparent molecular weights of 418 and gas chromatography/mass spectrometry characteristics suggesting the structure of 1,4,5-pent-1enetricarboxylic acid, equivalent to OSA-TCA shortened by four methylene units. Except for tricarballylate, all OSA-related compounds chromatographed as pairs presumed to correspond to the minor cis- and major trans-isomers of OSA. However, the relative areas of the smaller, paired, OSA-related peaks, D,E and F, G in Figure 1, varied somewhat from sample to sample because of small amounts of coeluting compounds.

Figure 2 shows the mass spectra of the major trans-isomers of OSA and its apparent tricarboxylic acid (OSA-TCA), which are major organic acid peaks in the urine of children excreting OSA and its by-products. Spectral data for OSA and its nine associated metabolites are also listed in Table 3 . Although one of the apparently OSA-related components, tricarballylate (1,2,3-propanetricarboxylate), also occurs as a by-product of beet-sugar and maple-sugar refining, its presence in all patients fed OSAmodified starch whom we studied, but rare presence in only trace amounts in the urine of other formula-fed infants, suggests that it is produced from OSA by $\omega$-oxidation followed by three complete cycles of $\beta$-oxidation, as indicated in the proposed scheme of OSA metabolism (Fig. 3). The tentative identifications of the other metabolites of OSA are based on interpretations of

Table 1. Clinical and laboratory data

\begin{tabular}{|c|c|c|c|c|c|c|c|c|c|c|}
\hline \multirow[b]{2}{*}{ Patient } & \multirow[b]{2}{*}{ Age } & \multirow[b]{2}{*}{ Diagnosis } & \multirow[b]{2}{*}{ Formula } & \multirow[b]{2}{*}{$\begin{array}{l}\text { Urine } \\
\text { collection }\end{array}$} & \multicolumn{4}{|c|}{ Urinary metabolites (mg/g creatinine) } & \multirow{2}{*}{$\begin{array}{c}\text { Plasma } \\
\text { OSA } \\
\text { level } \\
(\mu \mathrm{mol} / \mathrm{L})\end{array}$} & \multirow{2}{*}{$\begin{array}{c}\text { Plasma } \\
\text { carnitine } \\
\text { level }(\mathrm{F} / \mathrm{T})^{*} \\
(\mu \mathrm{mol} / \mathrm{L})\end{array}$} \\
\hline & & & & & OSA & $\begin{array}{c}\text { OSA } \\
\text { metabolites }\end{array}$ & Glutarate & $\begin{array}{l}\text { 2-Keto- } \\
\text { glutarate }\end{array}$ & & \\
\hline 1 & $2 \mathrm{mo}$ & Hypotonia, dev delay & Nutramigen & Random & 1353 & 497 & 7.0 & 560 & & \\
\hline 2 & $16 \mathrm{mo}$ & Cerebral palsy & Nutramigen & 24-h & 221 & 211 & 18.1 & 97 & 17.3 & $36 / 53$ \\
\hline 3 & $3 y$ & Mult cong anomalies & Nutramigen & $24-\mathrm{h}$ & 121 & 73 & 3.6 & 45 & & \\
\hline 4 & $10 \mathrm{mo}$ & Cerebral palsy & Nutramigen & Random & 297 & 420 & 19.0 & 258 & & \\
\hline 5 & $6 y$ & Myopathy & Vivonex T.E.N. & $24-\mathrm{h}$ & 199 & 508 & 9.8 & 56 & & $15 / 16$ \\
\hline 6 & $10 \mathrm{mo}$ & $46, X X, 8 \mathrm{p}+$ & Nutramigen & $24-\mathrm{h}$ & 507 & 158 & 15.6 & 168 & 57.9 & $40 / 53$ \\
\hline 7 & $9 \mathrm{mo}$ & Werdnig-Hoffmann disease & Pregestimil & Random & 465 & 2168 & 31.7 & 677 & 16.9 & \\
\hline 8 & $2 y$ & Mental retardation & Pregestimil & Random & 167 & 523 & 29.0 & 78 & 48.7 & $15 / 31$ \\
\hline 9 & $3 \mathrm{mo}$ & Prematurity & Pregestimil & Random & 130 & 625 & 6.0 & 40 & & $44 / 59$ \\
\hline 10 & $6 y$ & Cerebral palsy & Nutramigen & 24-h & 187 & 598 & 10.9 & 140 & 9.5 & \\
\hline 11 & $5 y$ & Hydrocephalus & Pregestimil & Random & 291 & 253 & 15.6 & 48 & & \\
\hline 12 & $5 \mathrm{mo}$ & Recurrent diarrhea & Pregestimil & Random & 566 & 527 & 13.6 & 284 & & \\
\hline 13 & $5 \mathrm{mo}$ & Seizure disorder & Nutramigen & Random & 527 & 403 & 70.8 & 300 & & \\
\hline 14 & $5 \mathrm{mo}$ & Milk allergy & Pregestimil & Random & 175 & 522 & 11.3 & 44 & & \\
\hline 15 & $4 \mathrm{mo}$ & Recurrent diarrhea & Pregestimil & Random & 326 & 197 & 18.4 & 276 & & \\
\hline 16 & $3 \mathrm{mo}$ & Prematurity & Pregestimil & 24-h & 439 & 901 & 23.2 & 286 & & \\
\hline 17 & $2 \mathrm{mo}$ & Zellweger syndrome & Pregestimil & Random & 138 & 591 & 8.4 & 281 & & \\
\hline \multicolumn{11}{|c|}{ Normal range } \\
\hline 3 mo-1 y & & & & & & & $1-12$ & $30-200$ & & $20-60 / 25-80$ \\
\hline $1-6 y$ & & & & & & & $1-8$ & $25-120$ & & $20-60 / 25-80$ \\
\hline
\end{tabular}

${ }^{*} \mathrm{~F} / \mathrm{T}$, free/total. 


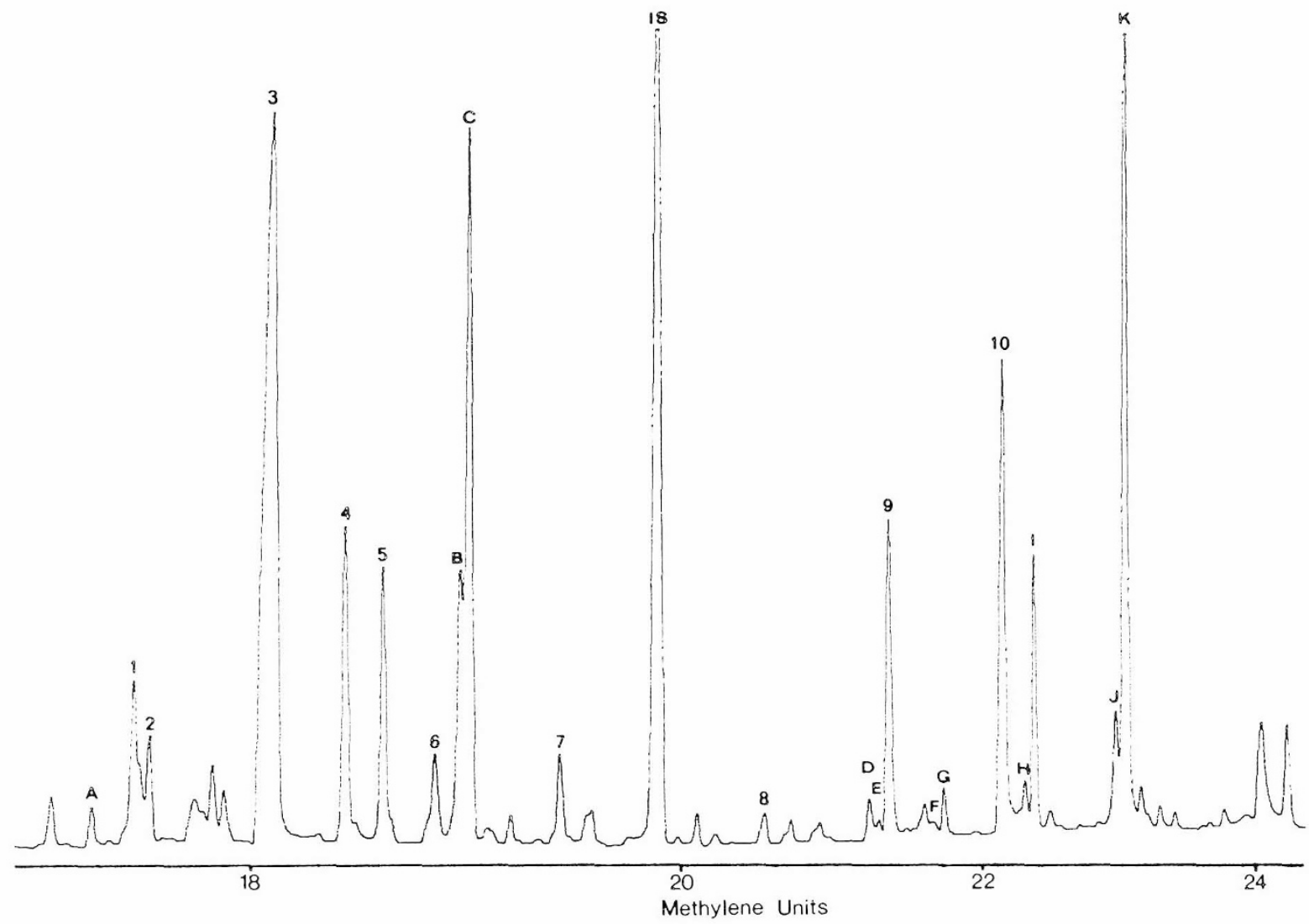

Fig. 1. Expanded region from 19 to 24 methylene units of a flame ionization gas chromatogram of urinary organic acid TMS ester/ethers from an infant fed Nutramigen. Known compounds related to OSA are tricarballylate $(A)$ and cis- and trans-2-octenylsuccinic acid $(B, C)$. Other tentatively identified OSA-related compounds are cis- and trans-1,2,7-hept-4-enetricarboxylic acid (D,E); cis- and trans-7-hydroxy-OSA (F,G), cis- and trans8(?)-hydroxy-OSA $(H, I)$, and cis- and trans-OSA-TCA $(J, K)$. Compounds A through $\mathrm{K}$ are further described in Tables 2 and 3. Other organic acids identified here for purposes of comparison are: aconitate (1), homovanillate (2), hippurate-diTMS (3), citrate (4), 3-OH-phenylhydracrylate (5), vanillylmandelate (6), indole-3-acetate (7), internal standard (undecanedioate) (IS), palmitate (8), 3-OH-hippurate-diTMS (9), and 4-OH-hippurate$\operatorname{diTMS}(10)$.

Table 2. Octenylsuccinate and related metabolites

\begin{tabular}{|c|c|c|c|c|c|}
\hline $\begin{array}{l}\text { Peak in } \\
\text { Figure } 1 \\
\end{array}$ & $\begin{array}{c}\text { Proposed organic acid structure } \\
\text { (as TMS derivative) }\end{array}$ & $\begin{array}{c}\text { Molecular } \\
\text { weight }\end{array}$ & $\begin{array}{c}\text { Methylene } \\
\text { units* }\end{array}$ & $\begin{array}{c}\text { Proposed } \\
\text { biosynthesis from } \\
\text { octenylsuccinate }\end{array}$ & $\begin{array}{c}\text { Proposed } \\
\text { structure } \\
\text { in Figure 2 } \\
\end{array}$ \\
\hline A & Tricarballylateł & 392 & 17.35 & $\begin{array}{l}\omega \text {-oxidation }+3 \\
\text { cycles } \beta \text {-oxidation }\end{array}$ & $\mathrm{V} \dagger$ \\
\hline B & $c$-2-octenylsuccinate $\dagger$ & 372 & 18.99 & Parent compound & $\mathrm{I} \dagger$ \\
\hline $\mathrm{C}$ & $t$-2-octenylsuccinate $\dagger$ & 372 & 19.03 & Parent compound & $\mathrm{I} \dagger$ \\
\hline $\mathrm{D}$ & c-1,2,7-hept-4-enetricarboxylate & 446 & 21.17 & $\begin{array}{l}\omega \text {-oxidation }+1 \text { cycle } \\
\beta \text {-oxidation }\end{array}$ & IV \\
\hline E & $t$-1,2,7-hept-4-enetricarboxylate & 446 & 21.23 & $\begin{array}{l}\omega \text {-oxidation }+1 \text { cycle } \\
\beta \text {-oxidation }\end{array}$ & IV \\
\hline $\mathrm{F}$ & c-7-hydroxyoctenylsuccinate & 460 & 21.75 & $\omega-1$ hydroxylation & VII \\
\hline G & t-7-hydroxyoctenylsuccinate & 460 & 21.81 & $\omega-1$ hydroxylation & VII \\
\hline $\mathrm{H}$ & c-hydroxyoctenylsuccinate & 460 & 22.28 & ? $\omega$-hydroxylation & ?II \\
\hline I & t-hydroxyoctenylsuccinate & 460 & 22.35 & $? \omega$-hydroxylation & ?II \\
\hline $\mathrm{J}$ & c-1,2,9-non-4-enetricarboxylate & 474 & 22.95 & $\omega$-oxidation & III \\
\hline K & $t$-1,2,9-non-4-enetricarboxylate & 474 & 23.03 & $\omega$-oxidation & III \\
\hline
\end{tabular}

* On OV-1 methylsilicone capillary column.

$\uparrow$ Identity confirmed by gas chromatography/mass spectrometry of authentic standard.

the mass spectra of their TMS and methyl-TMS derivatives and on the relative retention times of the derivatives on methylsilicone capillary columns. For example, the mass spectra of the methyl-TMS derivatives of isomers $F$ and $G$ had prominent fragments at $\mathrm{m} / \mathrm{e}=117$, characteristics of $\omega$-1-hydroxy compounds, and apparent molecular weights of 344 , consistent with a methyl-TMS derivative of monohydroxy OSA. The reconstructed ion currents of several urine specimens were also searched by selected ion analysis for possible keto-derivatives of OSA, but none in amounts greater than $5 \mathrm{mg} / \mathrm{g}$ creatinine could be identified with certainty. Other compounds that appear to be associated with ingestion of OSA-containing formulas, and which may also be metabolites of OSA, were found in some urine specimens, but their identities are less certain.

The mean concentration of tricarballylate, the apparent product of microsomal $\omega$-oxidation of OSA to OSA-TCA followed 

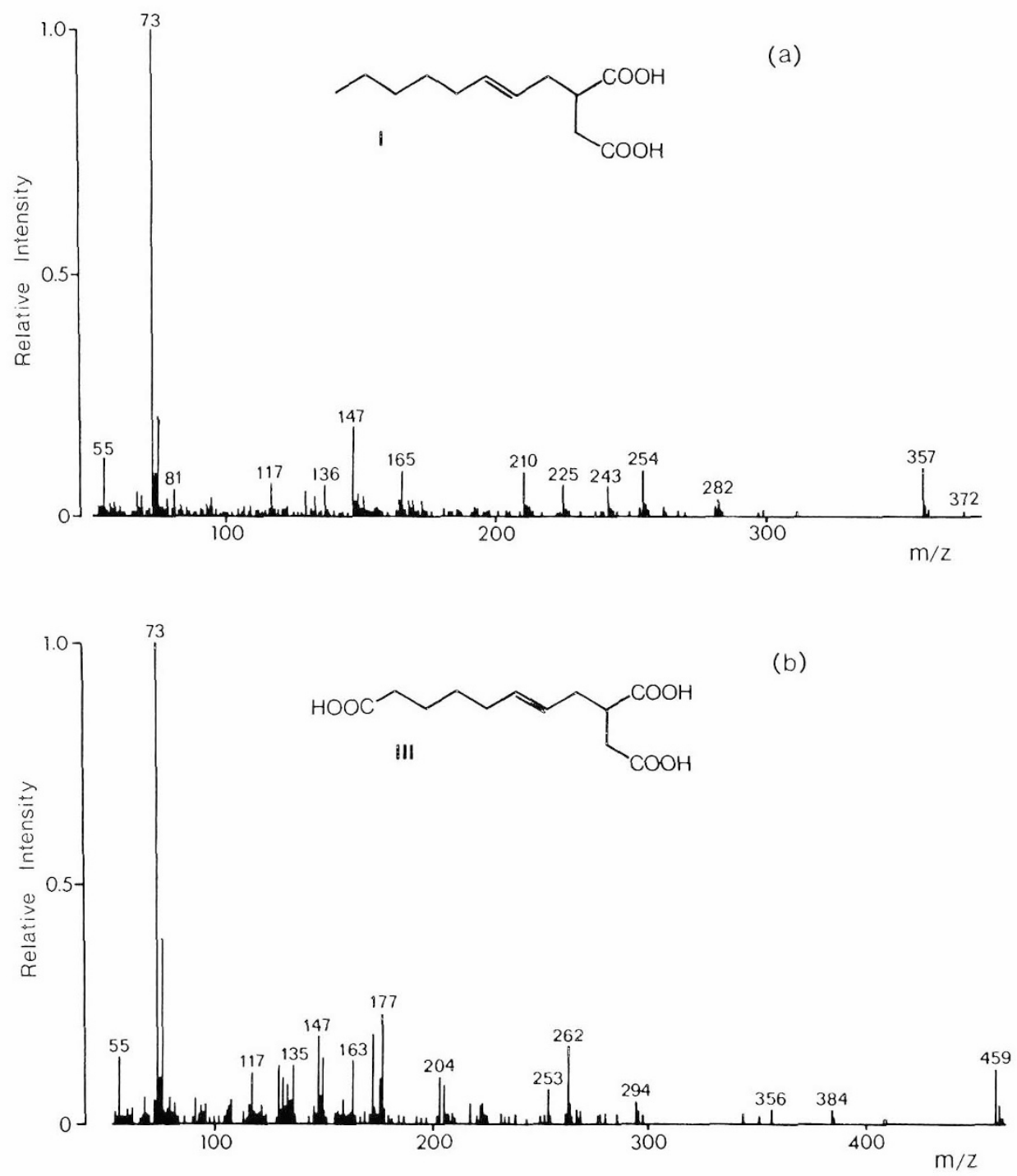

Fig. 2. Electron impact mass spectra from the chromatogram shown in Figure 1: $a$, trans-2(2'-octenyl)succinate; and $b$, a compound consistent with the tricarboxylic acid $\omega$-oxidation product of $a$, trans-1,2,9-non-4-enetricarboxylate (compound III, Fig. 3).

by three cycles of $\beta$-oxidation, was $31.4 \mathrm{mg} / \mathrm{g}$ creatinine (range 6.0 to $91.5 \mathrm{mg} / \mathrm{g}$ creatinine). In most patients the urinary concentration of tricarballylic acid was $5-10 \%$ of the concentration of OSA-TCA. However, the urine of the patient with Zellweger syndrome (no. 17), a generalized disorder of peroxisomal function including peroxisomal $\beta$-oxidation, contained no tricarballylate despite a urinary level of the presumed precursor, OSATCA, of $440 \mathrm{mg} / \mathrm{g}$ creatinine. Peaks D and E, corresponding to compounds consistent with OSA-TCA shortened by one cycle of $\beta$-oxidation, also were absent from this patient's urine.

In addition to OSA and its metabolites, many urine samples showed significant increases in the levels of glutarate and 2ketoglutarate (Table 1). Children fed Pregestimil, which contains medium-chain triglycerides, also excreted large amounts of medium-chain fatty acid metabolites: octanoate, adipate, suberate, sebacate, 5-hydroxyhexanoate, and 7-hydroxyoctanoate. In some cases, the increased levels of glutarate were substantial, and a primary diagnosis of glutaric aciduria often was entertained. However, in five patients (nos. 2, 5, 6, 10, and 11) urinary levels of glutarate and 2-ketoglutarate were found to be normal after changing to a standard infant formula or protein-hydrolysate formula not containing OSA. The excretion of 2-ketoglutarate had a relatively high correlation with the total excretion of OSA and its metabolites $(r=0.88)$, but a much weaker correlation existed between glutarate and OSA + OSA metabolites $(r=$
0.22). Extraction of organic acids and fatty acids from two OSAcontaining formulas (Nutramigen and Pregestimil), both before and after alkaline hydrolysis, showed the expected presence of OSA and FFA (from triglycerides) but no measurable amount of glutarate, 2-ketoglutarate, or any of the nine OSA-associated metabolites found in urine. We do not know at this time if the increased urinary levels of glutarate and 2-ketoglutarate reflect increased plasma levels of these compounds, increased renal secretion, or decreased tubular reabsorption caused by OSA, OSA-metabolites, or other formula components. Although two patients were also found to have mildly to moderately depressed plasma free and total carnitine levels (Table 1), there was no apparent correlation between levels of free or total carnitine and the levels of OSA, its metabolites, or other organic acids.

In addition to large amounts of OSA and its metabolites in urine, measurable levels of OSA were found in the plasma of the several children for whom both urine and plasma samples were available (Table 1). The highest level found was $57.9 \mu \mathrm{mol} / \mathrm{L}$ in a child fed Nutramigen. No other metabolites of OSA, all of which should be more readily excreted than OSA, were detected in plasma at levels greater than $1 \mu \mathrm{g} / \mathrm{mL}$. For comparison, typical levels of palmitate, one of the major FFA in nonfasting plasma, range from 30 to $150 \mu \mathrm{mol} / \mathrm{L}$ in our laboratory.

\section{DISCUSSION}

The organic aciduria associated with OSA-modified cornstarch is formally similar to the organic aciduria caused by the anticon- 
Table 3. Mass spectral ions of octenylsuccinic acid and associated organic acids

\begin{tabular}{|c|c|c|c|c|c|c|c|c|c|c|c|c|}
\hline \multirow{2}{*}{$\begin{array}{r}\text { Organic acid } \\
\text { Tricarballylic acid-triTMS }\end{array}$} & \multirow{2}{*}{$\begin{array}{c}\begin{array}{c}\text { Peak in } \\
\text { Figure } \\
1\end{array} \\
\mathrm{~A}\end{array}$} & \multirow{2}{*}{$\begin{array}{c}\begin{array}{c}\text { Molecular } \\
\text { weight }\end{array} \\
392\end{array}$} & \multicolumn{10}{|c|}{ Ten most abundant ions* } \\
\hline & & & $\begin{array}{r}73 \\
100\end{array}$ & $\begin{array}{r}147 \\
70\end{array}$ & $\begin{array}{r}377 \\
56\end{array}$ & $\begin{array}{l}75 \\
35\end{array}$ & $\begin{array}{r}185 \\
28\end{array}$ & $\begin{array}{r}217 \\
21\end{array}$ & $\begin{array}{l}55 \\
18\end{array}$ & $\begin{array}{r}149 \\
17\end{array}$ & $\begin{array}{r}184 \\
12\end{array}$ & $\begin{array}{l}69 \\
11\end{array}$ \\
\hline c-2-(2'-octenyl $)$ succinic acid diTMS & B & 372 & $\begin{array}{r}73 \\
100\end{array}$ & $\begin{array}{l}75 \\
24\end{array}$ & $\begin{array}{r}147 \\
21\end{array}$ & $\begin{array}{r}357 \\
14\end{array}$ & $\begin{array}{l}55 \\
13\end{array}$ & $\begin{array}{r}165 \\
12\end{array}$ & $\begin{array}{r}254 \\
12\end{array}$ & $\begin{array}{r}210 \\
10\end{array}$ & $\begin{array}{r}117 \\
8\end{array}$ & $\begin{array}{r}225 \\
5\end{array}$ \\
\hline 1-2-(2'-octenyl)succinic acid diTMS & $\mathrm{C}$ & 372 & $\begin{array}{r}73 \\
100\end{array}$ & $\begin{array}{l}75 \\
22\end{array}$ & $\begin{array}{r}147 \\
20\end{array}$ & $\begin{array}{r}357 \\
19\end{array}$ & $\begin{array}{l}55 \\
13\end{array}$ & $\begin{array}{r}254 \\
11\end{array}$ & $\begin{array}{r}165 \\
10\end{array}$ & $\begin{array}{r}74 \\
9\end{array}$ & $\begin{array}{r}210 \\
9\end{array}$ & $\begin{array}{r}282 \\
4\end{array}$ \\
\hline c-1,2,7-hept-4-enetricarboxylic acid-triTMS & $\mathrm{D}$ & 446 & $\begin{array}{r}73 \\
100\end{array}$ & $\begin{array}{l}75 \\
42\end{array}$ & $\begin{array}{r}149 \\
26\end{array}$ & $\begin{array}{r}147 \\
20\end{array}$ & $\begin{array}{r}204 \\
19\end{array}$ & $\begin{array}{r}177 \\
12\end{array}$ & $\begin{array}{r}328 \\
12\end{array}$ & $\begin{array}{l}55 \\
11\end{array}$ & $\begin{array}{r}431 \\
9\end{array}$ & $\begin{array}{r}266 \\
8\end{array}$ \\
\hline 1-1,2,7-hept-4-enetricarboxylic acid-triTMS & E & 446 & $\begin{array}{r}73 \\
100\end{array}$ & $\begin{array}{l}75 \\
35\end{array}$ & $\begin{array}{r}149 \\
31\end{array}$ & $\begin{array}{r}204 \\
24\end{array}$ & $\begin{array}{r}147 \\
23\end{array}$ & $\begin{array}{r}328 \\
17\end{array}$ & $\begin{array}{r}431 \\
14\end{array}$ & $\begin{array}{l}55 \\
12\end{array}$ & $\begin{array}{r}266 \\
10\end{array}$ & $\begin{array}{r}225 \\
9\end{array}$ \\
\hline c-7-hydroxyoctenylsuccinic acid-triTMS & $\mathrm{F}$ & 460 & $\begin{array}{r}73 \\
100\end{array}$ & $\begin{array}{l}75 \\
42\end{array}$ & $\begin{array}{r}147 \\
21\end{array}$ & $\begin{array}{r}117 \\
20\end{array}$ & $\begin{array}{r}262 \\
15\end{array}$ & $\begin{array}{l}55 \\
10\end{array}$ & $\begin{array}{r}210 \\
10\end{array}$ & $\begin{array}{r}163 \\
9\end{array}$ & $\begin{array}{r}172 \\
9\end{array}$ & $\begin{array}{r}445 \\
4\end{array}$ \\
\hline t-7-hydroxyoctenylsuccinic acid-triTMS & G & 460 & $\begin{array}{r}73 \\
100\end{array}$ & $\begin{array}{l}75 \\
31\end{array}$ & $\begin{array}{r}147 \\
23\end{array}$ & $\begin{array}{r}117 \\
23\end{array}$ & $\begin{array}{r}262 \\
21\end{array}$ & $\begin{array}{r}163 \\
11\end{array}$ & $\begin{array}{r}210 \\
11\end{array}$ & $\begin{array}{r}172 \\
11\end{array}$ & $\begin{array}{l}55 \\
10\end{array}$ & $\begin{array}{r}445 \\
6\end{array}$ \\
\hline c-8-hydroxyoctenylsuccinic acid-triTMS (?) & $\mathrm{H}$ & 460 & $\begin{array}{r}73 \\
100\end{array}$ & $\begin{array}{l}75 \\
39\end{array}$ & $\begin{array}{r}262 \\
24\end{array}$ & $\begin{array}{r}147 \\
21\end{array}$ & $\begin{array}{r}149 \\
18\end{array}$ & $\begin{array}{r}172 \\
18\end{array}$ & $\begin{array}{r}163 \\
16\end{array}$ & $\begin{array}{l}55 \\
10\end{array}$ & $\begin{array}{r}445 \\
5\end{array}$ & $\begin{array}{r}329 \\
3\end{array}$ \\
\hline t-8-hydroxyoctenylsuccinic acid-triTMS (?) & I & 460 & $\begin{array}{r}73 \\
100\end{array}$ & $\begin{array}{l}75 \\
35\end{array}$ & $\begin{array}{r}262 \\
28\end{array}$ & $\begin{array}{r}147 \\
23\end{array}$ & $\begin{array}{r}172 \\
18\end{array}$ & $\begin{array}{r}149 \\
18\end{array}$ & $\begin{array}{r}163 \\
15\end{array}$ & $\begin{array}{l}55 \\
12\end{array}$ & $\begin{array}{r}129 \\
10\end{array}$ & $\begin{array}{r}445 \\
6\end{array}$ \\
\hline$c-1,2,9$-non-4-enetricarboxylic acid-triTMS & $\mathrm{J}$ & 474 & $\begin{array}{r}73 \\
100\end{array}$ & $\begin{array}{l}75 \\
36\end{array}$ & $\begin{array}{r}177 \\
21\end{array}$ & $\begin{array}{r}147 \\
19\end{array}$ & $\begin{array}{r}262 \\
17\end{array}$ & $\begin{array}{r}459 \\
17\end{array}$ & $\begin{array}{r}172 \\
16\end{array}$ & $\begin{array}{l}55 \\
13\end{array}$ & $\begin{array}{r}163 \\
12\end{array}$ & $\begin{array}{r}149 \\
12\end{array}$ \\
\hline t-1,2,9-non-4-enetricarboxylic acid-triTMS & $\mathrm{K}$ & 474 & $\begin{array}{r}73 \\
100\end{array}$ & $\begin{array}{l}75 \\
40\end{array}$ & $\begin{array}{r}147 \\
22\end{array}$ & $\begin{array}{r}262 \\
21\end{array}$ & $\begin{array}{r}172 \\
20\end{array}$ & $\begin{array}{r}177 \\
20\end{array}$ & $\begin{array}{r}163 \\
15\end{array}$ & $\begin{array}{r}149 \\
14\end{array}$ & $\begin{array}{r}129 \\
14\end{array}$ & $\begin{array}{r}459 \\
11\end{array}$ \\
\hline
\end{tabular}

* The numbers in the top row of each pair of rows are the individual fragment sizes (m/e), and the numbers in the bottom row are the $\%$ base peak.

vulsant valproate (4). Both OSA and valproate (2-propylpentanoate) are medium-length, branched-chain organic acids that appear in the urine together with variable amounts of by-products produced by a combination of microsomal $\omega$ - and $\omega$-1-oxidation and mitochondrial or peroxisomal $\beta$-oxidation. Moreover, both valproate and OSA-containing formulas appear to have secondary effects on the metabolism of patients receiving them. Medication with valproate increases urinary levels of medium-chain dicarboxylic acids and 3-hydroxyisovalerate, a metabolite of leucine, whereas OSA-containing formulas were associated in our patients with increased urinary levels of both glutarate and 2-ketoglutarate.

OSA in OSA-modified cornstarch is chemically bound in esterlinkages to carbohydrate hydroxyl groups, but appears to be at least partially liberated from the starch, possibly by intestinal esterases, and absorbed. OSA-modified starch typically contains approximately $2.7 \%$ OSA by weight and constitutes from 2.0 to $2.6 \mathrm{~g} / 100 \mathrm{kcal}$ of the most frequently used formulas known to contain OSA-modified starch. At a formula intake of $100 \mathrm{kcal} /$ $\mathrm{kg} / \mathrm{d}$, the average amount of OSA ingested is approximately $50-$ $70 \mathrm{mg} / \mathrm{kg} / \mathrm{d}$. Our measurements indicate that at least 10 to $25 \%$ of ingested OSA was absorbed and ultimately excreted in the urine of the patients we studied. At this time, however, we have no information about other possible metabolic or excretory fates of ingested OSA.

Because complete medication information was available for only about half of the children, we were not able to identify possible effects of specific medications on the excretion of OSA and its metabolites. Theoretically, however, the large variation in the apparent proportion of OSA that was metabolized could be influenced by medications, such as anticonvulsants, that induce or otherwise modify the activity of microsomal oxidases or other pathways of xenobiotic metabolism. Substantial intrinsic variation in individual absorption and metabolism of OSA may occur, and the possibility that some or all of the metabolites are produced by the action of intestinal bacteria and then absorbed must also be considered.

The causes of the apparently formula-dependent increased levels of glutarate and 2-ketoglutarate found in the urine of many of our patients are unclear. The increased 2-ketoglutarate levels, which correlated with total OSA levels and possibly formula intake, may be related to other formula components such as citrate, which is a major component $(0.5 \mathrm{~g} / 100 \mathrm{kcal})$ of Nutramigen and Pregestimil and a precursor of 2-ketoglutarate in the citric acid cycle. The more variably increased levels of glutarate may be an idiosyncratic response to OSA or other formula components. Of note, also, is the apparent complete absence of $\beta$-oxidation metabolites of OSA-TCA in a child with Zellweger syndrome, which suggests that $\beta$-oxidation of OSA-TCA occurs in the peroxisome. However, more detailed studies will be required to establish the sequence and sites of metabolism of OSA.

OSA-modified starch is currently approved by the United States Food and Drug Administration as a food additive. Before the use of OSA-modified cornstarch in infant formulas, toxicity 


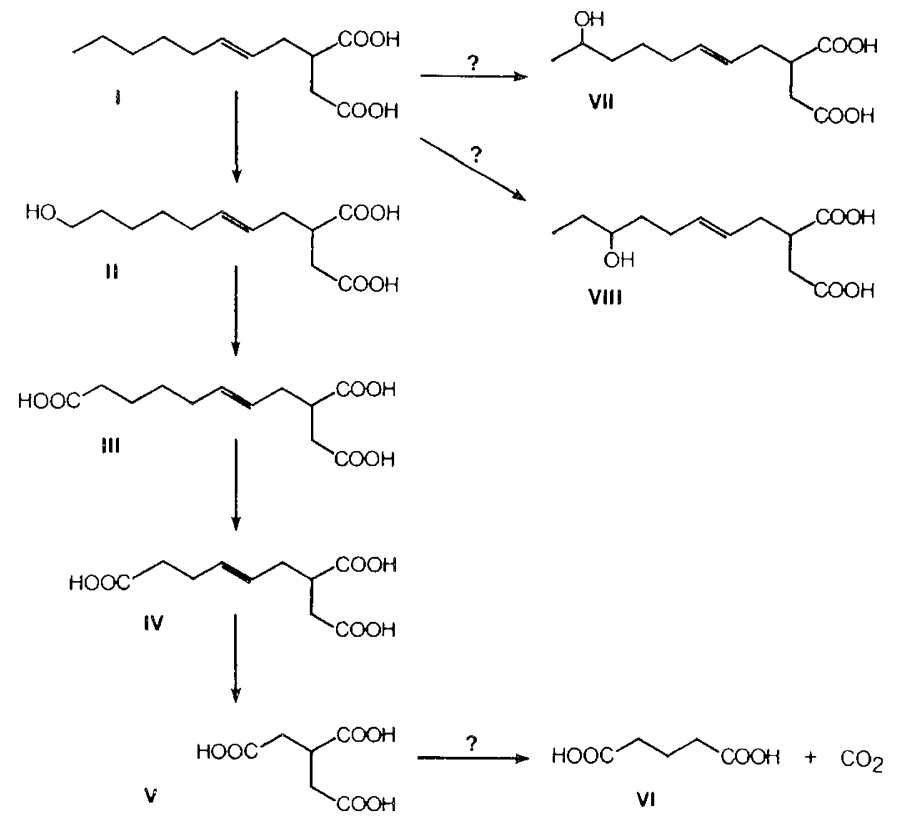

Fig. 3. Proposed metabolism of 2-octenylsuccinate (compound I). The conversions of compounds I to II and II to III would be expected to occur by microsomal $\omega$-oxidation activity, whereas the conversions of compounds III to IV and IV to V are proposed to occur by cycles of mitochondrial or peroxisomal $\beta$-oxidation after formation of a terminal coenzyme A ester. Compounds VII and VIII are other possible products of microsomal oxidase action on 2-(2'-octenyl)succinate. Table 2 gives additional information about the chemical and chromatographic characteristics of the urinary compounds shown or tentatively assigned to these structures. Note that a different labeling system (I-VIII) is used in this figure to differentiate the experimental peaks (A-K) of Figure 1 from compounds in the above theoretical metabolic scheme. Both are included in Table 2.

testing of the additive had apparently been limited to several studies in rats, one of which has been published (5). Although no adverse effects specific to OSA-starch were identified in that study, to our knowledge, there have been no published studies on the pharmacokinetics of free OSA in man nor on the effects of free OSA on the growth and development of young animals. Because, as shown here, substantial blood levels of free OSA can accumulate in some children, our laboratory is continuing to evaluate the pharmacokinetics of OSA, individual variation in the handling of this material, and possible secondary metabolic effects.

In summary, a complex pattern of organic acids has been identified in the urine of children fed formulas containing OSAmodified cornstarch and further characterized by gas chromatography/mass spectrometry. The major components of the organic aciduria include unmodified OSA, at least nine metabolites that appear to arise from OSA by a combination of microsomal and mitochondrial or peroxisomal oxidative processes, and apparently secondary increases in the levels of glutarate and 2-ketoglutarate. Because this acquired organic aciduria can be mistaken for a primary metabolic disease and has led to unnecessary and expensive additional testing in some children, it is important that physicians requesting urinary organic acid quantification and laboratories performing these studies be aware of the effects of OSA-modified starch on urinary organic acid profiles. Furthermore, because OSA is a xenobiotic compound and appears to undergo absorption and metabolism similar to valproate and other drugs, the possibility of drug interactions or other adverse clinical effects should be considered.

Acknowledgments. The author thanks Humphrey Chemical Company for generously providing $2-(2$-octenyl)succinic anhydride for these studies and Drs. Piero Rinaldo and George Thomas for helpful discussions.

\section{REFERENCES}

1. Giordano G, McMurrary WJ, Previs SF, Welch RD, Rinaldo P 1990 Identification of $2-\left(2^{\prime}\right.$-octenyl $)$ succinic acid in urine. Rapid Commun Mass Spec-
trom 4:170-172

2. Tanaka K, Hine DG, West-Dull A, Lynn TB 1980 Gas-chromatographic method of analysis for urinary organic acids. Clin Chem 26:1839-1846

3. Ng KJ, Andresen BD, Hilty MD, Bianchine JR 1983 Identification of long chain dicarboxylic acids in the serum of two patients with Reye's syndrome. J Chromatogr 276:1-10

4. Gugler RJ, Von Unruh GE 1980 Clinical pharmacokinetics of valproic acid Clin Pharmacokinet 5:67-83

5. Buttolph ML, Newberne PM 1980 Subchronic studies in rats fed octenylsuccinate-modified food starch. Food Cosmet Toxicol 18:357-362 